\title{
Creation retold: Use of Scripture and tradition in Sirach 16:24-17:14
}

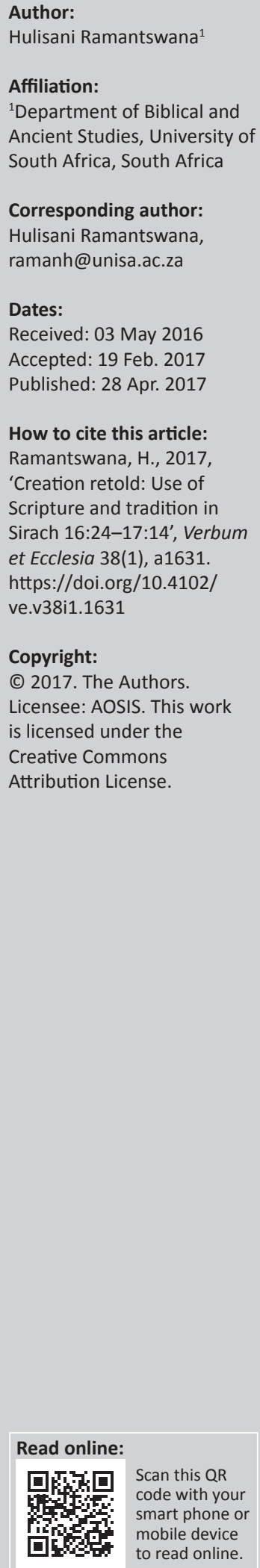

This article examines the use of Scripture and tradition in Sirach 16:24-17:14, which is a retelling of the creation stories. Ben Sira as an interpreter of Scripture utilised interpretive traditions or exegetical motifs that were in circulation during his time to provide instruction for his generation. His indebtedness to Scripture is evident from the quotations from Scripture and his use of scriptural language. In his retelling of the creation stories, he made use of the exegetical motifs that were in circulation, adapting them within the wisdom interpretive framework. He also rejected the tendency to blame evil on external agencies such as fallen angels and downplayed the gap between the creation process and the giving of the law at Sinai.

Intradisciplinary and/or interdisciplinary implications: The article is an exegetical inquiry of the extra-biblical text of Ben Sira in dialogue with Scripture and with other exegetical traditions which were in circulation in the Second Temple period. The article highlights the indebtedness of Ben Sira to both Scripture and tradition, and also noting Ben Sira's own creativity in the use of Scripture and tradition in his retelling of creation story.

\section{Introduction}

During the Second Temple period, several documents were produced from the different social and intellectual movements. Sheppard (1980:13) highlights that 'wisdom became a theological category associated with understanding of canon ... In this sense, wisdom became a hermeneutical construct for interpreting sacred Scripture'. Within the wisdom hermeneutic construct, the sages were supposedly shifting 'non wisdom material from Torah and the Prophets to a new context and concern for wisdom like that of Proverbs and perhaps Qohelet' (Sheppard 1980:15). ${ }^{1}$ Sheppard's focus in his study was on tracing biblical elements to their source and then comparing the original non-wisdom context of Old Testament passages with their new roles in the context of wisdom in Ben Sira.

Some scholars argue that Ben Sira in his use of Scripture brought together the wisdom tradition and the Torah as a way of recasting the wisdom framework (Berg 2013; Collins 1997:54; Goering 2009:1-20; Schnabel 1985:26-63). It should be noted, however, that wisdom as a hermeneutical construct or a literary genre did not belong to a single intellectual movement, rather, it was utilised within the various intellectual movements within Second Temple Judaism. ${ }^{2}$ Ben Sira is generally regarded as belonging to a tradition that linked the wisdom tradition with the study of the law and the temple in support of the Aaronite priesthood (Sir 45:17; cf. 45:5) through Simon, in contrast to the authors of 1 Enoch and the Aramaic Levi Document, who were inclined to mantic forms of wisdom and so represented the marginalised priests, and linked the wisdom tradition with such biblical figures as Enoch and Levi (see Goering 2009; Horsley 2005; Mermelstein 2014; Nickelsburg 1981; Stone 1988; Wright 2005).

The focus in this study is on Ben Sira's use of existing interpretive traditions in the retelling of creation in Sirach 16:24-17:14. The interpreter, as Schniedewind (1999:158) puts it, 'is both the heir to and the creator of tradition'; consequently, this study examines Ben Sira's indebtedness to Scripture and interpretive traditions. It will be argued that Ben Sira's retelling of the creation 1.Ben Sira was probably also aware of rival Jewish traditions; he probably had in mind the Enochic and other pre-Qumranic traditions
when he wrote some of his polemics. For example, although the book of 1 Enoch is usually classified as apocalyptic, the text itself
claims to be a compilation of wisdom books ( 1 En $5: 8 ; 82: 1 \mathrm{~d} ; 82: 2 \mathrm{a} ; 32: 3 \mathrm{~b})$. We find in Sirach $34[31]: 1-8$ a polemic against dreamers
that was probably aimed at the Enochic tradition. In his praise of the fathers, as some have suggested, Ben Sira intentionally left out
Ezra, who was of the lineage of the Zadokite, and he does not praise Zadok, thus avoiding any affirmation of the Zadokite priesthood that was so important for the pre-Qumranic tradition (Argall 1995:8, 9, 17-35; Duggan 2005:201-210).

2.Boccaccini (2008:29) is pointed in this regard: 'Literary genres are not Judaism, but worldviews that shaped, influenced, or were used by, different varieties of Judaism. The definition of Ben Sira as a sapiential text tells us a lot about the spreading and pervasiveness of this literary genre and worldview, but does not clearly locate the document within a determined intellectual movement or theology, or social group'. 
stories makes use of common interpretive traditions or exegetical motifs and adapts them within the wisdom interpretive framework. Thus, Ben Sira, as an interpreter of Scripture, retold the creation story making use of existing exegetical motifs, which he inherited and was also transmitting through his work. ${ }^{3}$

\section{The ideal scribe as interpreter of Scripture}

The book of Ben Sira was originally written in Hebrew between 200 and 180 BCE at a time when Aramaic was the lingua franca in Palestine. Since 1896 to date, several Hebrew manuscripts have been recovered; however, no full Hebrew text of the book has been recovered. Beentjes (2006:135) highlights that Ben Sira composed his book in Hebrew as an attempt to link his work with the Hebrew Scriptures' traditions that were in circulation during his time. In 132 BCE, Ben Sira's grandson translated his grandfather's book into Greek for the Jewish community in Alexandria. Notwithstanding the challenges encountered in the translation process, this study relies on the grandson's Greek translation, yet not discarding the importance of the extant Hebrew texts. ${ }^{4}$ The grandson's Greek translation, while likely altering the Hebrew parent text in small and great ways, is still a worthy witness to the extant exegetical motifs in circulation during the time, which he was most likely familiar with, not only through his grandfather's wisdom text but also through other existing literary works and from oral circulation of such exegetical motifs.

Ben Sira regarded the instruction he was giving through his book as divinely inspired and by implication prophetic in character and thus worthy of authority within his interpretive community. The prophetic character of the book is evidenced by the claim of divine inspiration:

I will again pour out teaching like prophecy, and leave it to all future generations. Observe that I have not laboured for myself alone, but for all who seek wisdom. (Sir 24:33-34, New Revised Standard Version [NRSV])

If the great Lord is willing, he will be filled with the spirit of understanding; he will pour forth words of wisdom of his own and give thanks to the Lord in prayer. The Lord will direct his counsel and knowledge, as he meditates on his mysteries. (Sir 39:6-7, NRSV)

Ben Sira's assertion in these passages is not so much of new revelation freshly revealed by God to him as it is his instruction or his teaching, which is grounded in earlier written prophetic revelation. In 39:6-8, the inspiration Ben Sira claims comes through the 'spirit of understanding'

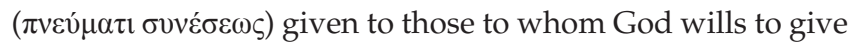
it (Perdue 2005:138).

3.We will follow Kugel's (1998:27) definition of exegetical motifs: 'An exegetical motif is an explanation of a biblical verse (or paraphrase or word therein) that becomes the basis for some ancient writer's expansion or other alteration of what Scripture the basis for some ancient winter actually says: in paraphrasing or summarising Scripture, the ancient writer detail or otherwise deviates from mere repetition or restatement of the Bible'.

4.Ben Sira's grandson in translating the Hebrew text to Greek surely had to wrestle with common translation challenges (Cadbury 1955).
The authoritative word now required divinely inspired men to interpret and to teach God's people. This, as others have suggested, led to the cessation of living prophecy or oral prophecy. As Blenkinsopp (1977:128-137) suggests, in the post-exilic era, prophecy did not end but was merely relocated: prophecy became absorbed into the cult, which accounts for 'scribal prophecy' and 'clerical prophecy', and consequently scribal teaching replaced prophecy. Ben Sira does not claim to have received any knowledge about the future (Perdue 2005:140). He even rejects other claims of inspiration, including divination (קסם), omenology (נחש:) and the interpretation of dreams (חלומות; 34:1-8 [31:1-8]; Perdue 2005:140). He regards himself as one who had received divine illumination to instruct others on the basis of earlier Scripture about the observance of the law.

Ben Sira not only regarded himself as divinely illuminated to give instructional prophecy but also regarded his writing to be having the same authoritative status as earlier Scripture. Recently, Berg (2013:154-157) has argued that Ben Sira was probably aware of the Qumran sectarian claims of exclusive divine revelation in 4QInstructions (4Q415-418); the writers regarded themselves as עם רוח, 'a people with spirit', and regarded others as רוח בשר 'a spirit of flesh' or 'fleshy people'. Ben Sira, by claiming divine illumination for his book, was in a way refuting the tendency to monopolise divine illumination by the Qumran sectarian group. This is evident in his continual assertion that he has not laboured for himself alone but also for those of future generations:

I will again pour out teaching like prophecy, and leave it to all future generations. Observe that I have not laboured for myself alone, but for all who seek wisdom. (Sir 24:33-34)

Consider that I have not laboured for myself alone, but for all who seek instruction. Hear me, you who are great among the people, and you leaders of the congregation, pay heed! (Sir 33:16-19)

Instruction in understanding and knowledge I have written in this book, Jesus son of Eleazer son of Sira of Jerusalem, whose mind poured forth wisdom. Happy are those who concern themselves with these things, and those who lay them to heart will become wise. For if they put them into practice, they will be equal to anything, for the fear of the Lord is their path. (Sir 50:27-29)

Ben Sira describes himself not as a prophet or a priest but as a wise scribe who is devoted to studying and actualising the Scripture. For Ben Sira, Scripture 'was no longer merely a record of events from the distant past of one people, nor prophetic oracles delivered to a specific audience, but words of eternal validity that were relevant, therefore, to anyone in any age' (e.g. Sirach 44:16; Kugel 1998:12); God's word was the written word to which he devoted himself and formed the basis of his inquiry. He describes an ideal scribe ( $\gamma \rho \alpha \mu \mu \alpha \tau \varepsilon u ́ \varsigma)$ in 39:1-5:

How different the one who devotes himself to the study of the law of the Most High! He seeks $(\dot{\varepsilon} \kappa \zeta \eta \tau \tau \dot{\varepsilon} \omega)^{6}$ out the wisdom of all

5.In about 20 passages, Ben Sira calls his readers to "keep the law" (1:26. $15: 1,15$ $19: 20 ; 21: 11 ; 23: 27 ; 28: 6,7 ; 29: 1 ; 32: 22,23 ; 35: 1$, 2; 37:12; 44:20; cf. 2:16; 6:36) and in other instances not to 'break' or 'transgress' the law (10:19; 19:24; 49:4; cf. $41: 8)$.

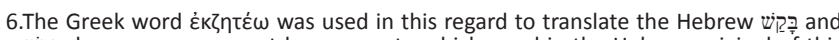
שา section has not been recovered. 
the ancients, and is concerned with prophecies; he preserves the sayings of the famous and penetrates the subtleties of parables; he seeks ( $\dot{\varepsilon} \kappa \zeta \eta \tau \dot{\varepsilon} \omega)$ out the hidden meanings of proverbs and is at home with the obscurities of parables. He serves among the great and appears before rulers; he travels in foreign lands and learns what is good and evil in the human lot. He sets his heart to rise early to seek the Lord who made him, and to petition the Most High; he opens his mouth in prayer and asks pardon for his sins.

The ideal scribe in this case is interested in revealed revelation: the law of the Most High, the wisdom of all the ancients, the prophecies, the sayings of the famous, the parables and the proverbs. Ben Sira even concludes his book by inviting others to come into the 'house of instruction' (בבית מדרש), which is a place where a wise teacher would instruct others in wisdom or the fear of the Lord (Sir 51:23). The term midrash, as Bloch (1978:30) has observed, was used by the Chronicler to allude 'to the historical works which glossed Scripture for the purpose of instruction and edification'.7 During the postexilic era, written documents started to gain an authoritative status and became objects of study and interpretation. As a result, sages (like Ben Sira) came to play an important role as interpreters of the sacred word. In Leiman's (1976:31) terms, Ben Sira had a 'canon consciousness', meaning that he was conscious of the sacred and authoritative writings in the community's life, faith and praxis. ${ }^{8}$

In his use of the Scripture, Ben Sira rarely uses the usual quotation formulas; rather, what we find is the 'anthological' or 'compositional' use of Scripture (Dimant 2004:379-419; Murphy 1996:67; Sheppard 1980:100-119). ${ }^{9}$ Scriptural language had become, as it were, part of his own vocabulary, and in a way 'biblical elements become subservient to the independent aim and structure of its new context' (Dimant 2004:382). However, Ben Sira in his interpretive framework did not simply utilise scriptural language; he was also utilising existing exegetical motifs in his interpretation of the Scripture. It therefore cannot be merely assumed that his interpretations reflected his own creativity. As will be made evident below, he was indebted to existing interpretive traditions or exegetical motifs in his interpretation of the authoritative writings. In order to identify the exegetical motifs that he was using, attention will be paid to other

7.The Chronicler, as Schniedewind (1995:241) argues, interprets the received tradition in order to exhort the post-exilic community to seek the Lord, thus making the book of Chronicles a historical sermon and not so much a historical work.

8.Leiman (1976:14) defines canon as those books 'accepted by Jews as authoritative for religious life and/or doctrine, and whose authority is binding upon Jewish people for all generations'. See also Seeligmann (1953:150-181).

9.In terms of identifying compositional elements in a book like Sirach, Dimant distinguishes three ways in which biblical elements may be interwoven: (1) implicit quotations, paraphrases of at least three words stemming from a recognisable biblical context; (2) allusions; (3) models and motifs (Dimant 2004:400-419). In a more elaborate fashion, Sheppard distinguishes six means of referring to specific Scriptural texts or traditions: (1) full citations of a biblical text (at least several words in length) without alteration in wording; (2) partial citation of a single biblical text with alteration in wording, including additions and omissions; (3) the use of key words or phrases as Stichwort connections to specific texts or traditions; (4) allusions to specific texts or traditions; e) paraphrase of specific texts or traditions; (5) imaginative choice of metaphors that allows for a variety of free association (5) imaginative choice of metaphors that allows for a variety of free association with biblical imagery (Sheppard 1980:100-102). However, Beentjes (2000:596-598) argues that Ben Sira does use introductory formulae as markers of his scriptura references: (1) In the Hebrew text of Ben Sira, halô', which is used as an introduction to a rhetorical question, explicitly functions to introduce a passage from Scripture (Sir 14.15, 38.5, 46.4, 35.15). (2) The conjunction k1 is used to introduce a biblica quotation (Sir 5:1-8); (3), and hakkatûb ('it is written') is used as an introductory formula, followed by a quotation (Sira 48:10c, where Mal 3:23b-24a is introduced)
Second Temple writings that tend to display similar exegetical motifs. As Kugel (1998) points out, exegetical motifs:

were the very fabric of ancient biblical interpretation. Individual authors may have put their own stamp on the motifs that they inherited, and even the choice to include or not include a given motif may reflect the tastes, ideology, or other particulars of a specific author. (p. 28)

\section{Creation retold in Sirach 16:24-17:14}

In the retelling of creation, Ben Sira was drawing from such biblical texts as the creation accounts in Genesis 1-3 (Gn 1:12:4a and Gn 2:4b-3:24), as well as the creation theme in Proverbs 8 and Job 28, Exodus, Deuteronomy and the Psalter. ${ }^{10}$ In retelling the creation story, Ben Sira was not engaged in a process of conflating biblical texts together; rather, he was intentionally reinterpreting the creation stories by alluding to and citing the biblical text, expanding on the biblical text and incorporating exegetical motifs into his story. Thus, in retelling creation, Ben Sira was also involved in the process of creating new exegetical motifs.

Sirach 16:24-17:14 opens up in a didactical fashion in keeping with conventions of wisdom literature (Table 1).

The key to the didactic is the introductory words of this section in v. 24: 'Listen to me, my child/son'.11 This didactic formula is used often in wisdom literature when instruction is about to be given (Pr 1:8; 4:10; 5:7; 7:24; 23:19). The same didactic formula is also found in Sirach 3:1, 31:22; 39:13. The assertions that Ben Sira intends to make in this retelling should be understood from the vantage point of wisdom.

\section{Sirach 16:26-28: Heavenly bodies or angels?}

In this section we focus on the exegetical motif of heavenly bodies or angels as projected in Sirach 16:26-28 (Table 2).

This strophe, together with the subsequent strophes, alludes to the Genesis 1-3 creation accounts. In so doing, Ben Sira continues the creation theme, which he had

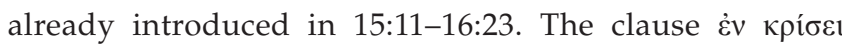
кvpíov ... $\dot{\alpha} \pi$ ' $\dot{\alpha} \rho \tilde{\eta} \varsigma$ ('When the Lord created ... in the

TABLE 1: Sirach 16:24-25.

\begin{tabular}{|c|c|}
\hline Greek Text & NRSV \\
\hline 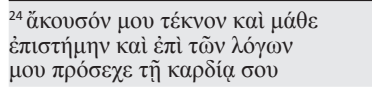 & $\begin{array}{l}{ }^{24} \text { Listen to me, my child, and acquire } \\
\text { knowledge, and pay close attention to my } \\
\text { words. }\end{array}$ \\
\hline 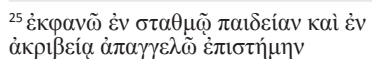 & $\begin{array}{l}{ }^{25} \text { I will impart discipline precisely and } \\
\text { declare knowledge accurately. }\end{array}$ \\
\hline
\end{tabular}

NRSV, New Revised Standard Version.

10. Several studies have been done to highlight the intertextual relations between Sirach 16:24-17:14 and the biblical texts; see among others Sheppard (1980:1983); Marböck (1999:134-153); Schökel (1978); Fletcher-Louis (2004:69-113); Perdue (2005); Argall (1995:135-164); Berg (2013).

11.I have bracketed 'O Son' because the Greek word TÉkvov does not appear in the Hebrew manuscript and the Syriac translation. The Greek translator probably provided the word in keeping with the other didactic calling, as may be found in Proverbs $(1: 8 ; 4: 10 ; 5: 7 ; 7: 24 ; 23: 19)$ and other instances in Sirach's book $(3: 1,12$ $6: 32 ; 7: 23 ; 31: 22 ; 34: 33 ; 39: 13 ; 41: 6,14 ; 44: 12$ ). 
TABLE 2: Sirach 16:26-28.

\begin{tabular}{|c|c|}
\hline Greek Text & NRSV \\
\hline 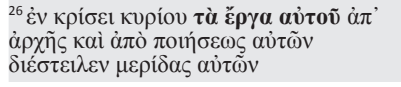 & $\begin{array}{l}{ }^{26} \text { When the Lord created his works from } \\
\text { the beginning, and, in making them, } \\
\text { determined their boundaries, }\end{array}$ \\
\hline 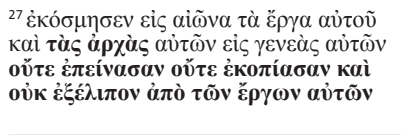 & $\begin{array}{l}{ }^{27} \text { he arranged his works in an eternal } \\
\text { order, and their dominion for all } \\
\text { generations. } \\
\text { They neither hunger nor grow weary, } \\
\text { and they do not abandon their tasks. }\end{array}$ \\
\hline 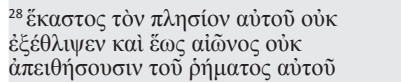 & $\begin{array}{l}{ }^{28} \text { They do not crowd one another, } \\
\text { and they never disobey his word. }\end{array}$ \\
\hline
\end{tabular}

beginning', v. 26) recalls especially Genesis $1: 1$ and 2:4b. Instead of $\dot{\varepsilon} v \kappa \rho i ́ \sigma \varepsilon 1$, we are reading here $\dot{\varepsilon} v \kappa \rho i ́ \tau \varepsilon 1$, as there was probably a scribal error in this regard. In 17:1, we find

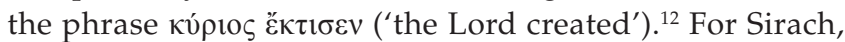

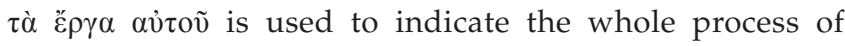
creation, which is in line with his usage of the term elsewhere. ${ }^{13}$ In 15:14, Ben Sira states 'He himself created

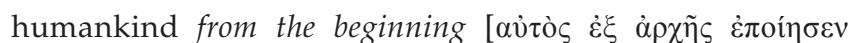
$\alpha v \theta \rho \omega \pi \mathrm{ov}]$, and he left them in the power of their own free choice'. In the wisdom hymn in 24:9, wisdom states, 'Before the ages, in the beginning [ $\dot{\alpha} \pi$ ' $\alpha \rho \chi \tilde{\eta} \varsigma]$, he created me, and for all the ages I shall not cease to be'. For Sirach, the creation account in Genesis actually tells about how everything came into existence, as every created thing lies within the beginning of the creation age.

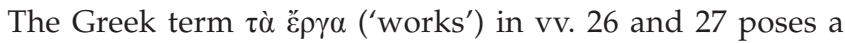
challenge, as it can be understood in more than one way, depending on the context. The first option may be to read it as 'works', by implication the heavenly bodies - stars, moon, sun, etc. If it is construed in this manner, then we would read this section as recalling the theme of God, orchestrating his works into a single harmonious cosmos that functions in perfect obedience to 'his word' (cf. 43:9-10, Ps. 148:6; Isa 40:26; Skehan \& Di Lella 1987:281; Sheppard 1980:73). This rendering also finds support with other ancient interpreters ${ }^{14}$ :

Contemplate all the events in heaven, how the lights in heaven do not change their courses, and how each rises and sets in order, each at its proper time, and they do not transgress their law. (1 En 2:1)

The Stars shone in their watches and were glad; he called them and they said 'Here we are', they shone with gladness for him who made them. (Bar 3:34)

This way of reading by our ancient interpreters is one which stands in continuity with the way they read passages such as Psalms 148:6 and Isaiah 40:6.

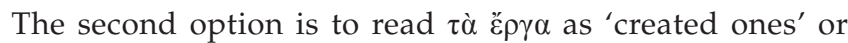
'angels', taking into consideration that the term $\alpha \rho \chi \eta$ ('dominion or rule') is used by other ancient interpreters

12.This is unlike the Septuagint, which translates בר in Genesis with the verb poie, w. As in Ben Sira, the New Testament uses the verb $\kappa \tau i \zeta \omega$ and its noun form exclusively for divine activity in creation.

13.There are other instances where Sirach uses $\dot{\alpha} \pi$ ' $\dot{\alpha} \rho \chi \tilde{\eta} \varsigma$ without alluding to the creation theme $(36: 10 ; 39: 25,32 ; 51: 20)$.

14.Cf. Pss. Sol. 18:10-12; Odes Sol. 16:12-12; Ep Jer 60. to refer to the heavenly powers or rulers (Argall 1995:136). The connection comes out clearly in Jude 1:6 which states:

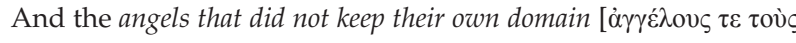

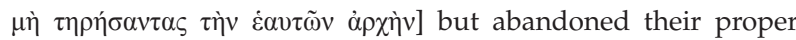
dwelling, he has kept in eternal chains in deepest darkness for the judgment of the great day.

The term $\dot{\alpha} \rho \chi \eta$ is often used by Paul to refer to heavenly powers or rulers (Rm 8:38; 1 Cor 15:24; Eph 3:10; Col 1:16). Kugel (1998) notes:

Ben Sira's wording paraphrases Deut. 32:8, which was understood to refer to angels being allotted their 'portions'; what is more, the idea that celestial creatures never need food or rest and do not interfere or overlap with one another in their heavenly missions - all these are elsewhere frequently asserted to be true angels. (p. 49) $)^{15}$

Sirach 16:26-28, along with 17:17, which picks up the theme of assigning to a ruler or an angel each nation except for Israel, who is the Lord's own portion, ${ }^{16}$ and 17:32, which contrasts the heavenly hosts (angels) and human beings, is most probably speaking of the creation angels who had charge over the galaxy and later on over all the nations except Israel, the Lord's own portion. The identification of angels as agents ruling the stars comes out more forcefully in 1 Enoch $75: 1 ; 80: 6 ; 82: 4-20$. We have already highlighted the aspect of the fallen angels in the quotation from Jude 1:6, which, although is a later text, reflects an interpretive tradition that was already in circulation.

Furthermore, Ben Sira also seems to allude to the fall of angels in Sirach 16:7: 'He did not forgive the ancient giants who revolted in their might' (emphasis added), echoing Genesis 6:1-5, which talks about the sons of God intermingling with the daughters of humans. The subject of the fall of angels is fully developed in 1 Enoch 6:1-12:10. When the angel intermingled with the daughters of man, Enoch states, 'and the women became pregnant and gave birth to great giants whose heights were three hundred cubits' (1 En $7: 2$ ). These books, which originated around the same time, were gleanings from a common tradition. However, we should note that the creation stories in Genesis 1-3 do not mention the creation of angels, nor is anything said in the Old Testament as to when they were created. However, there was no doubt among the ancient interpreters that angels were also created within the 6 days of creation: on the sixth day 15.'When the Most High apportioned the nations, when he divided humankind, he
fixed the boundaries of the peoples according to the number of the gods; the Lord's own portion was his people, Jacob his allotted share' (Dt 32:8-9).

16.The idea of angels overseeing the other nations except for Israel, the Lord's own portion, is also picked up by other ancient interpreters: 'He [God] chose Israel to be his people. He made them holy and gathered them apart from all mankind. For there are many nations and many peoples, and all belong to Him. He made spirits [that is, angels] rule over all in order to lead them astray from following him. But over Israel made no angel or spirit rule because he alone is their ruler' (Jub 15:3032). '[At the time of the tower of Babel] God called out to the seventy angels that surround his throne of glory and said to them: "Come and let us confuse their surround his throne of glory and said to them: "Come and let us confuse their speech". And whence do we know that God called out to them? It is said, "Come le us go down" [Gen 11:7]; it does not say "Let me go down" but "Let us ..." And whence do we know that he cast lots among them [the angels]? It says, "When the Most High was apportioning [that is, allotting] nations ..." [Deut. 32:8], and his lot fell upon Abraham and his household, as it says, "But God's own portion is his people, Jacob his allotted heritage"' (Pirqe R. El., 24). 
'the heavens and the earth were completed, and all their host' (Gn 2:1). Although in agreement that the angels were created during the creation activity, ancient interpreters differ as to which day of creation the angels were created (11QPs ${ }^{a} ;$ Herm. Vis. 4:1; Jub. 2:2; Cav. Tr. 1; Augustine, City of God 11:19; 2 En. 29:3; Tag. Ps.-J Gen 1:26; Midrash Konen; Pirqe R. El. 4; Gen Rab. 1:3).

It should be noted that although Ben Sira does not systematically follow the 7-day structure of the Genesis 1 creation account, for him the creation of $\tau \grave{\alpha}$ है $\rho \gamma \alpha$, which may be taken to refer to angels, precedes the creation of humanity. Even so, Ben Sira is not so much interested in crafting a sustained doctrine of heavenly angels, as we find in other works of his contemporaries such as Enoch and Jubilees; his interest is rather on humans' responsibility for their actions and for choosing to do good rather than evil. As Boccaccini (2008:36) notes, Ben Sira downplays the idea that evil should be attributed to external factors such as angels or the Satan (Sir 15:11-20; 21:27). The chief adversary is the self and the failure to follow the law of life.

\section{Sirach 16:29-17:10: Humanity's mortality and glory}

In this section we focus on the exegetical motif of humanity's mortality and glory as projected in Sirach 16:29-17:10 (Table 3).

Depending on how one reads 16:26-28, the phrase אà $\mu \varepsilon \tau \grave{\alpha}$ $\tau \alpha \tilde{\tau} \tau \alpha$ ('after these things') in 16:29 may suggest that God,

\begin{tabular}{|c|c|}
\hline Greek Text & NRSV \\
\hline 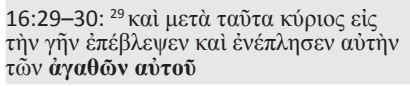 & $\begin{array}{l}{ }^{29} \text { Then the Lord looked upon the earth, } \\
\text { and filled it with his good things. }\end{array}$ \\
\hline 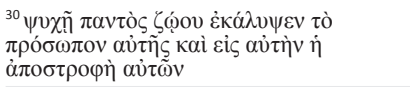 & $\begin{array}{l}{ }^{30} \text { With all kinds of living beings he } \\
\text { covered its surface, and into it they } \\
\text { must return. }\end{array}$ \\
\hline 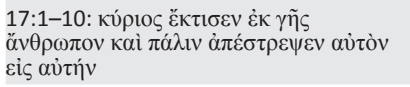 & $\begin{array}{l}\text { 17.1The Lord created human beings } \\
\text { out of earth, and made them return to } \\
\text { it again. }\end{array}$ \\
\hline 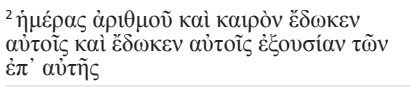 & $\begin{array}{l}{ }^{2} \text { He gave them a fixed number of days, } \\
\text { but granted them authority over } \\
\text { everything on the earth. }\end{array}$ \\
\hline 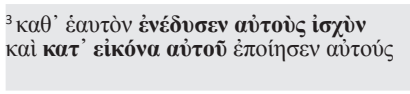 & $\begin{array}{l}{ }^{3} \mathrm{He} \text { endowed them with strength like } \\
\text { his own, and made them in his own } \\
\text { image. }\end{array}$ \\
\hline 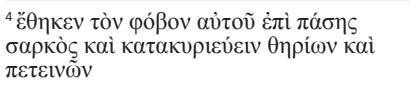 & $\begin{array}{l}{ }^{4} \mathrm{He} \text { put the fear of them in all living } \\
\text { beings, and gave them dominion over } \\
\text { beasts and birds. }\end{array}$ \\
\hline 5 & 5 \\
\hline 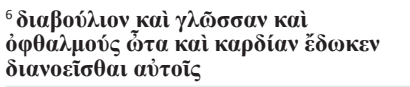 & $\begin{array}{l}{ }^{6} \text { Discretion and tongue and eyes, } \\
\text { ears and a mind for thinking he gave } \\
\text { them. }\end{array}$ \\
\hline 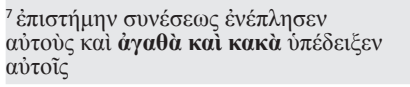 & $\begin{array}{l}{ }^{7} \text { He filled them with knowledge and } \\
\text { understanding, and showed them good } \\
\text { and evil. }\end{array}$ \\
\hline 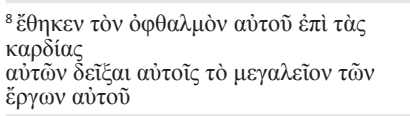 & $\begin{array}{l}{ }^{8} \mathrm{He} \text { put the fear of him into their } \\
\text { hearts to show them the majesty of his } \\
\text { works. }\end{array}$ \\
\hline 9 & - \\
\hline 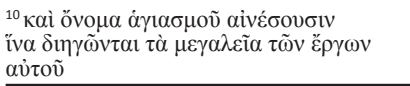 & $\begin{array}{l}{ }^{10} \text { And they will praise his holy name, } \\
\text { to proclaim the grandeur of his works. }\end{array}$ \\
\hline
\end{tabular}

after creating all his other works, was now ready to fill the earth with living beings, though according to Genesis 1 it was not filled with living beings until the fifth day; or it may suggest that angels were created before any other living beings including humanity. The heavenly creatures (angels), unlike earthly living beings, which are mortal, are immortal; they neither feel hunger nor grow weary, nor do they abandon their tasks. However, there are some similarities between heavenly beings and earthly creatures, specifically humankind: they all receive their specific function from their Creator.

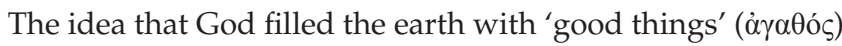
is an allusion to the daily aesthetic judgement that creation is 'good' (Gn 1:4, 10, 12, 18, 21, 25). However, the 'good' here appears to be referring specifically to the filling of the uninhabited earth by living beings. In 39:16-19, 33-35 à $\alpha \theta$ ó ('good') is used with reference to all of God's works: 'All the works of the Lord are very good, and whatever he commands will be done at the appointed time' (v. 16):

All the works of the Lord are good, and he will supply every need in its time. No one can say, 'This is not as good as that,' for everything proves good in its appointed time. (vv. 33-34)

For Ben Sira, all of Lord's works are good for the purpose they are made to fulfil at their appointed times. However, the fact that everything is 'good' did not imply perfection, the absence of evil or undistorted creation. For Ben Sira, the created works come in pairs: 'good and evil ... life and death ... poverty and riches' (Sir 11:4; 33:14-15; 42:42). The duality of the created order also comes out in Sirach 39:12-35, in which the goodness of creation is affirmed. However, in this text, Ben Sira resolves the problem of the co-existence of good and evil by indicating that good things are created for good people, whereas bad things or evil things are for sinners (Sir 39:25). In this duality of the created order, everything is good for the purpose for which it was created (Sir 39:33).

\section{Mortality of earthly living beings and humankind}

In 16:30-17:2, Ben Sira deals with the issue of mortality. The arrangement of the story in this regard is significant. In the creation stories in Genesis 1-3, the issue of mortality only comes up in Genesis 2:4b-3:24; it is not even alluded to in Genesis 1:1-2:4a. The issue of mortality or the frailty of humankind is given precedence over the issue of humankind being created in the image of God. Ben Sira presents mortality as a natural condition of all living beings. The creation account in Genesis does address the issue of mortality of humanity but is silent with regard to the mortality of all other living beings. Ben Sira is, in this case, weaving together elements from other scriptural passages that deal with the mortality of all living beings:

By the sweat of your face you shall eat bread until you return to the ground, for out of it you were taken; you are dust, and to dust you shall return. (Gn 3:19)

For the fate of humans and the fate of animals is the same; as one dies, so dies the other. They all have the same breath, and humans have 
no advantage over the animals; for all is vanity. All go to one place; all are from the dust, and all turn to dust again. Who knows whether the human spirit goes upward and the spirit of animals goes downward to the earth? (Eccl 3:20-21)

And the dust returns to the ground it came from, and the spirit returns to God who gave it. (Eccl 12:7)

Mortals cannot abide in their pomp; they are like the animals that perish. (Ps 49:12, 20)

How many are your works, O Lord, in wisdom you made them all; the earth is full of your creatures ... when you hide your face, they are terrified; when you take away their breath, they die and return to the dust. (Ps 104: 24-29)

If he should take back his spirit to himself, and gather to himself his breath, all flesh would perish together, and all mortals return to dust. (Job 34:14-15)

All these passages, except for Genesis 3:19, which are part of the creation stories and motifs that Ben Sira is reinterpreting, may all be classified under wisdom literature. All these wisdom passages tend to draw the connection between the mortality of animals and the mortality of human beings. It should also be noted that none of these passages are concerned with how death came to be the natural condition of all living beings, and neither is Ben Sira in this case. For Ben Sira, death is the natural condition of all living beings. Sirach 17:1 is based on Genesis 2:7 ('the Lord formed man out of the dust of the earth') and 3:19 ('by the sweat of your brow you will eat your food until you return to the ground, since from it you were taken; for dust you are and to dust you will return'). In 17:30, Ben Sira even goes to the extent of saying that 'not everything is within human capability, since human beings are not immortal'. Chapter 17 ends with a contrast between the heavenly host and human beings: 'He marshals the host of the height of heaven; but all human beings are dust and ashes' (v. 32). The original relation between mortality and man's sin in the garden is intentionally obscured (Sheppard 1980:76).

Human beings are not just mortal, they are also subjected to limitation: 'He gave them a fixed number of days' (17:2a.). In 18:9, Ben Sira even goes to the extent of saying that 'the number of days in their life is great if they reach one hundred years' (18:9). The Scriptures are not consistent in terms of number of years regarding this limitation; Genesis 6:3 mentions 'one hundred and twenty years'; Psalms 90:10 mentions 'seventy or eighty years'; Isaiah 65:20 says that in the renewed creation 'he who dies at a hundred will be thought a mere youth; he who fails to reach a hundred will be considered accursed'. Ben Sira was probably following Isaiah in setting the limit at a hundred, as a hundred in Isaiah is the minimum in the ideal creation. On the contrary, Ben Sira downplays the relation between human sin and death: death is understood in rabbinic sources to be a result of Adam and Eve's sin (Gen Rab. 17:2; 21:5; Exod Rab. 30:3; 38:2; Num Rab. 10:2; 23; Deut Rab. 9:8; Šabb 55b; j. Sanh. 72; b. Sanh. 20a; see also Philo, QE 1:16, 45; Allegorical Interpretation 1:105-106). For Ben Sira, death is a necessary limit of life; however, this does not negate humankind from God-given authority over everything on earth (Collins 1978:181).

\section{Humanity's dominion over the earth and his necessary functions}

In 17:3, Ben Sira appears to be evoking the motif of 'glorious clothing', which was a widespread motif. For Ben Sira, God

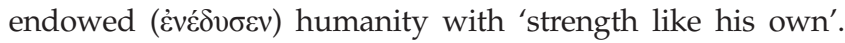
Ben Sira appears to be using this motif to heighten the idea that Adam and Eve were clothed with 'might' while in the garden of Eden, perhaps something like God's own might (Kugel 1998:118). In Sirach 49:16, Ben Sira speaks of Adam's splendour as surpassing the glory of Shem, Seth and Enosh. In Sirach 6:29-31, the 'glorious clothing' is also connected with divine wisdom. For other ancient interpreters, when Adam and Eve sinned, they were stripped of their glorious clothing, which is why they immediately realised that they were naked (Eph, Commentary on Genesis 2:4, 14; Apoc. Mos. 20:2; Gen Rab. 11:12; Cav. Tr. 1). This motif, as Kugel (1998:118) points out, probably originated in order to resolve the discomfort ancient interpreters felt with Adam and Eve's nakedness, which they came to realise following their disobedience.

Ben Sira's phrasing of 17:3-4 seems to be connected with Psalms 8:5-6, which is probably his base text for relating the motif of 'glorious clothing' with the motif of 'divine image' (Kugel 1998:81-82):

You made him [Adam] little less than God, and crowned [surround] him with glory and honour, You gave him dominion over Your creatures, and put all things under his feet. (Ps 8:5-6)

He endowed them with strength like his own, and made them in his own image. He put the fear of them in all living beings, and gave them dominion over beasts and birds. (Sir 17:3-4)

Although following the structural phrasing of Psalms 8:5-6, Ben Sira draws his phraseology from other texts. Sirach 17:3b, 'and made them in his own image', directly reflects Genesis 1:26a, 27a; however, this line is omitted in the Syriac version, which reads, 'In his wisdom he clothed them with strength and covered them with fear' (Sheppard 1980:77). The idea of humanity created in 'God's image' fascinated early interpreters (see Philo, Creation 134; Philo, QE 1:4; Wis 2:23; Col 1:15; Rm 5; 1 Cor 15) (Barret 1962; Belkin 1989:11-13; Davies 1955:47-48; Jevrell 1960; Levison 1988:84-85; Scroggs 1966). Sirach 17:4 is based on Genesis 1:28 and 9:2. The phraseology in v. 4a is more dependent on Genesis 9:2, which reads:

And the fear of you and the dread of you shall be on every beast of the earth, on every bird of the air, on all that move on the earth, and on all the fish of the sea. They are given into your hand.

By contrast, v. $4 \mathrm{~b}$ is more dependent on Genesis 1:28 which reads:

Then God blessed them and God said to them, 'Be fruitful and multiply; fill the earth and subdue it; have dominion over the fish of the sea, over the birds of the air, and over every living thing that moves on the earth.

This mandate was again given to Noah after the flood to reaffirm the creation mandate given to humankind as divine image bearers: 
The fear and dread of you shall rest on every animal of the earth, and on every bird of the air, on everything that creeps on the ground, and on all the fish of the sea; into your hand they are delivered. (Gn 9:2)

These two passages are coalesced to form a single statement, and both passages deal with the same theme: humankind's dominion over all living creatures.

In Sirach 17:6-8, humanity is endowed with sensory, psychological, intellectual and moral gifts so that 'they may glory in his wondrous deed and praise his holy name' (vv. 9-10; Skehan \& Di Lella 1987:282). The gifts endowed to man in vv. 6-8 are intended to explain the capacity of man as an image of God. As Kugel (1998:82) points out, the relating of divine image with the capacity of speech and discernment and the knowledge of right and wrong is also found in other early interpreters:

And after that he created man according to his image, and put in him eyes to see, ears to hear, heart to think, and reason to argue. (2 En 65:2)

By your wisdom you formed man to have dominion over the creatures that you made, and rule the world in holiness and righteousness, and pronounce judgment in the uprightness of soul. (Wis 9:2-3; see also 10:2)

[... Adam $]$ our father, You created in the image of your glory ... [the breath of life] You breathed into his nostrils, and with understanding and knowledge [You filled him ...]. ([4Q504] Words of the Luminaries, fragment 8; see also [4Q303] Meditation on the Creation A, lines 7-8 and [4Q304] Meditation on the Creation C, col. 2, lines 2-3)

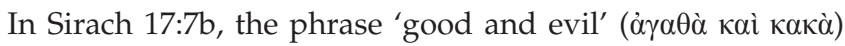
alludes to 'the tree of knowledge of good and evil' in Genesis 2:17 and 3:5, 22. Ben Sira does not use this phrase to evoke the aspect of Adam and Eve's testing and disobedience. As Collins (1997:59) puts it, 'there is no suggestion, however, that they were forbidden to eat from the tree of the knowledge of good and evil'. In the Genesis story, man only came to know the real effects of good and evil in a sense becoming like God after eating of the prohibited tree. According to Sheppard (1980:79-80), 'the knowledge of good and evil is made a witness to the presence of wisdom in the garden of Eden' as it is linked with 'discretion [שכל] [בינה]', which are cornerstones of wisdom. However, Ben Sira also seems to be suggesting that man already had the capability to distinguish between good and evil and it was not something that came as a consequence of man's disobedience. For Ben Sira, humankind from the beginning always had the free will to keep God's commandments or to disobey, to choose between life and death (Sir 15:14-17). However, the freedom of choice was not meant to be a license to sin (Sir 15:20). The idea of fear put in the heart of man in Sirach 17:8 is probably meant to allude to the theme he had already dealt with thoroughly in Sirach 1:1-2:17, concerning wisdom and the fear of the Lord:

The fear of the Lord is the beginning of wisdom; she is created with the faithful in the womb. She made among human beings an eternal foundation, and among their descendants she will abide faithfully. (Sir 1:14-15)
TABLE 4: Sirach 17:11-15.

\begin{tabular}{|c|c|}
\hline Greek Text & NRSV \\
\hline 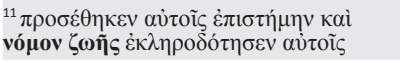 & $\begin{array}{l}{ }^{11} \mathrm{He} \text { bestowed knowledge upon them, } \\
\text { and allotted to them the law of life. }\end{array}$ \\
\hline 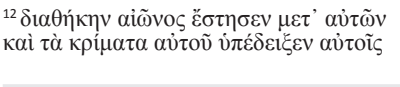 & $\begin{array}{l}{ }^{12} \text { He established with them an eternal } \\
\text { covenant, and revealed to them his } \\
\text { decrees. }\end{array}$ \\
\hline 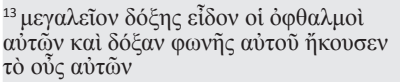 & $\begin{array}{l}{ }^{13} \text { Their eyes saw his glorious majesty, } \\
\text { and their ears heard the glory of his } \\
\text { voice. }\end{array}$ \\
\hline 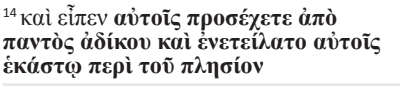 & $\begin{array}{l}{ }^{14} \mathrm{He} \text { said to them, 'Beware of all evil'. } \\
\text { And he gave commandment to each of } \\
\text { them concerning the neighbour. }\end{array}$ \\
\hline 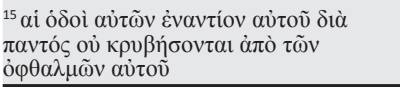 & $\begin{array}{l}{ }^{15} \text { Their ways are always before him, } \\
\text { they will not be hid from his eyes. }\end{array}$ \\
\hline
\end{tabular}

NRSV, New Revised Standard Version.

Bold indicated emphasis added.

\section{Sirach 17:11-15: Humanity and the law of life - Law at creation}

In this section, we focus on the exegetical motif of humanity and the law of life, which is about the law at creation (Table 4).

In Sirach 17:11-14, Ben Sira turns his attention to the law and echoes Israel's experience at Mt. Sinai as described in Exodus 19-20 and Deuteronomy 4-5. The phrase 'law of life' (vónov $\zeta \omega \tilde{c})$ occurs twice in Sirach, first in 17:11 and again only in the Hymn of Praise of the Father in 45:5, where it is identified as the Mosaic law:

He allowed him [Moses] to hear his voice and led him into the dark cloud and gave him the commandments face to face, the law of life and knowledge, so that he might teach Jacob the covenant, and Israel his decrees.

In both these cases, the law of life is related to knowledge and covenant. The locus classicus of the designation 'law of life' is Moses' final speech to Israel when they were at the verge of entering the Promised Land (Dt 30:15-20):

See, I have set before you today life and prosperity, death and adversity ... Choose life so that you and your descendants may live, loving the Lord your God, obeying him, and holding fast to him; for that means life to you and length of days, so that you may live in the land that the Lord swore to give to your ancestors, to Abraham, to Isaac, and to Jacob.

In Sirach 17:14, Ben Sira summarises the content of the law that the people received at Sinai (Flusser 1990:219-246) as two things: Firstly, it is the God-given charge to men: 'Beware of all unrighteousness'. This probably refers to the first part of the Decalogue, which prohibits idolatry and false worship, and enjoins Sabbath observance (Ex 20:1-11; Deut 5:6-15). Secondly, the words 'he [God] gave them commandment, to each man concerning his neighbour' refer to the second part of the Decalogue (Ex 20:12-17; Dt 5:16-21). Other ancient interpreters also tend to summarise the content of the law, believing that the entire Torah can be summarised in the two imperatives expressed in Deuteronomy 6:5, 'You shall love the Lord your God' (commandments regarding the laws between God and man), and Leviticus 19:18, 'You shall love your neighbour as yourself' (commandments regarding human relations). In the New Testament, Jesus summarises the law with what has come to be known as the Great 
Commandment: the love of God and the love of our neighbour (Mt 22:37-40). The two rules are also yoked together in other ancient interpreters: Testament of Dan 5:2; 7:6; Zebulun 5:1; Joseph 11:1 (see Flusser 1979:235-252). Flusser (1990:231) suggests that it is by chance that in rabbinic literature only one view is preserved, namely that the allencompassing principle of the ethics of the Torah is love of man. However, the sages did draw the distinction between the sins committed against God and those committed against man (Mishnah Yoma, VIII:9).

The implication of Sirach 17:11-14, as Collins (1997:59-60) points out, 'is that the "law of life," and the attendant choice between life and death, was given to humanity from the beginning'. The idea of the pre-existence of the Torah is clearly elaborated on in the book of Jubilees, which goes to great length to show that Torah was already active and living before Moses and was already in effect at creation, as written in the 'Heavenly Tablets' (Jub. 3:30-31; 4:5, 32; 6:17, 28-31; 18:19; 23:32; 31:32; 32:10, 28; 33:10; 49:8; see also Collins 1997:59-60). The idea of the pre-existence of the Torah is affirmed in rabbinic literature (Sifre Deut 37; b. Pesah 54a; b. Ned. 39b; Gen Rab. 1:1). This probably explains Ben Sira's apparent silence with regard to Adam and Eve's disobedience in 16:24-17:10; using the earlier model furnished in Proverbs 8 , he identifies God's eternal creative wisdom with 'the book of covenant of the Most High, the law that Moses commanded us as an inheritance for the congregation of Jacob' (Sir 24:23). The idea of creative wisdom is also found in various Palestinian Targums on Genesis 1:1: 'With wisdom the Lord created the heaven and the earth' (Tg. Neof.; see also Vermes 1992:223).

Mermelstein (2014:25-26) argues that 'law of life' and 'eternal covenant' in 17:11 and 17:12, respectively, refer specifically to the Sinai event wherein the Torah was given and an eternal covenant was established with Israel. In this reading, the Sinai event is the logical conclusion of the creation process. Pace Mermelstein, for Ben Sira, the Torah was already present in Eden, and thus the sin of Adam and Eve, like any other sin, was the transgression of the law. Ben Sira's retelling of creation downplays the gap between the creation narrative and the Sinai event, thus universalising the giving of the law and thereby rendering humanity in general without excuse for their evil and human beings in general capable of overcoming their wickedness. The universal, however, does not obliterate the particularity of the giving of the Torah to Israel. As Levison (1988:38) notes, 'Ben Sira hopes to persuade his audience that wisdom, which God reveals to humanity in general, found its particular expression in the revelation of Torah at Sinai'. Later Israel was God's possession in a unique way as he 'appointed a ruler for every nation' but making Israel his 'own portion' (Sir 17:17). For Ben Sira, it is in Israel as the Lord's own portion that Wisdom dwelt in a unique way, as declared in the Wisdom song in Sirach 24:8, 9, 12:

Then the Creator of all things gave me a commandment, and the one who created me assigned a place for my tent. And he said, 'Make your dwelling in Jacob, and in Israel receive your inheritance.' From eternity, in the beginning, he created me, and for eternity I shall not cease to exist. ... So I took root in an honoured people, in the portion of the Lord, who is their inheritance.

Thus, it is reasonable to conclude that for Ben Sira, the law of life, which was revealed to humanity in general, found its unique expression in Israel as it was given by Moses to the honoured people (Sir 45).

\section{Conclusion}

In the retelling of creation in Sirach 16:24-17:15, there are many general similarities with other ancient interpreters, which suggests that Ben Sira was also working with common exegetical motifs. The common exegetical motifs behind these ancient interpreters appear to have carried their own authority; however, Ben Sira was at home in adapting these traditions into his work and passing them down through his instruction, which was intended to be for generations to come. The traditional interpretations had become part of Ben Sira's own retelling of creation. However, in his retelling, Ben Sira does not reproduce traditional interpretations in their entirety; rather, he makes allusions to these traditions through phrases and words. It was also evident that Ben Sira's use of common exegetical motifs used by his contemporaries did not necessarily imply agreement or common understanding of the Scripture. By locating the giving of the 'law of life' within the creation process, he not only downplayed the gap between the creation and the Sinai narrative, he was also downplaying the common tendency among his contemporaries to blame wickedness and evil on external forces such as fallen angels or demons. For Ben Sira, human beings had to take responsibility for their actions in God's created order, as they are endowed with the ability to distinguish good from evil.

Ben Sira may be regarded as an interpreter of Scripture only if 'Scripture' is understood to be those writings that were regarded as 'sacred and authoritative writings' in the life of the community. The Scriptures needed to be interpreted and actualised in the life of the community, and so he served as a scribal prophet in that he regarded himself to be divinely inspired to instruct others from the Scripture, thereby making his teaching prophetic. His indebtedness to the Scripture is evident from quotations from the Scripture and his use of scriptural language. He was also an heir of a long, deep and rich web of traditional interpretation, which formed part of his understanding of the Scripture.

This article has shown that Ben Sira's indebtedness to traditional interpretation is an indication of some of the common traditions that he shares with other writers around his own time and from other later writings. Although Ben Sira's work predates most of the Second Temple writings we have drawn parallels with, this does not mean that he originated these interpretive traditions. Ben Sira was also an heir of earlier interpretive traditions. The same traditions are extant in other earlier works like Jubilees and Enoch, which originated around the same time frame as Ben Sira's book. 
Exegetical motifs, as Kugel (1998:28) points out, circulated widely and had their own authority.

\section{Acknowledgements Competing interests}

The author declares that he has no financial or personal relationships that may have inappropriately influenced him in writing this article.

\section{References}

Argall, R.A., 1995, 1 Enoch and Sirach: A comparative literary and conceptual analysis of the themes of revelation, creation and judgment, Scholars Press, Atlanta, GA.

Barret, C.K., 1962, From first Adam to last: A study in Pauline theology, Scribner's, New York.

Beentjes, P.C., 2000, 'Canon and Scripture in the book of Ben Sira', in M. Saeb $\varnothing$ (ed.) vol. 1 Hebrew Bible/Old Testament: The history of its interpretation, 2 vols, pp. 591-605, Vandenhoeck \& Ruprecht, Göttingen.

Beentjes, P.C., 2006, 'Prophets and prophecy in the book of Ben Sira', in M.H. Floyd \& R.D. Haak (eds.), Prophets, prophecy, and prophetic texts in second temple Judaism, pp. 135-150, T \& T Clark, New York.

Belkin, S., 1989, Philo's Midrash, Yeshiva, New York.

Berg, S., 2013, 'Ben Sira, the Genesis creation accounts, and the knowledge of God's will', Journal of Biblical Literature 131(1), 139-157. https://doi.org/10.2307/23488241

Blenkinsopp, J., 1977, Prophecy and canon, University of Notre Dame Press, Notre Dame, IN.

Boccaccini, G., 2008, 'Where does Ben Sira belong? The canon, literary genre, intellectual movement and social group of a Zadokite document', in G.G. Xeravits \& J. Zsengellér (eds.), Studies in the book of Ben Sira: Papers of the 3 rd International Conference on the Deuterocanonical Books, Shime'on Centre, Pápa, Hungary, 18-20 May, 2006, pp. 21-42.

Bloch, R., 1978, 'Midrash', in W.S. Green (ed.), transl. M. H. Callaway, Approaches to ancient Judaism theory and practice, vol. 1, pp. 29-50, Scholars Press, Missoula, MT.

Cadbury, H.J., 1955, 'The grandson of Ben Sira', Harvard Theological Review 48(4), 219-225. https://doi.org/10.1017/S0017816000025219

Collins, J.J., 1978, 'The root of immortality: Death in the context of Jewish wisdom', Harvard Theological Review 71, 179-185.

Collins, J.J., 1997, Jewish wisdom in the Hellenistic age, Westminster John Knox Press, Louisville, KY.

Davies, W.D., 1955, Paul and Rabbinic Judaism: Some elements in Pauline theology, SPCK, London.

Dimant, D., 2004, 'Use and interpretation of Mikra in the Apocrypha and Pseudepigrapha', in M.J. Mulder \& H. Sysling (eds.), Mikra: Text, translation, reading \& interpretation of the Hebrew Bible in ancient Judaism \& early Christianity, pp. 379-419, Hendrickson, Peabody, MA

Duggan, M.W., 2005, 'Ezra, scribe and priest, and the concerns of Ben Sira', in J. Corley $\&$ V.T.M. Skemp (eds.), Intertextual studies in Ben Sira and Tobit: Essays in honor of Alexander A. Di Lella, CBQMSup 38, pp. 201-210, Catholic Biblical Association of America, Washington, DC.

Fletcher-Louis, C.H.T., 2004, 'The cosmology of P and theological anthropology in the wisdom of Ben Sira', in C.A. Evans (ed.), Of scribes and sages: Early Jewish interpretation and transmission of Scripture, vol. 1, Ancient versions and traditions, pp. 69-113, T\&T Clark, London.
Flusser, D., 1979, 'There are two ways', in H. Safrai (ed.), Jewish sources in early Christianity (Hebrew), pp. 235-252, Tel Aviv University, Tel Aviv.

Flusser, D., 1990, 'The decalogue in the New Testament', in B.Z. Segal \& G. Levi (eds.), Ten Commandments in history and tradition, pp. 219-246, Magnes, Jerusalem.

Goering, G.S., 2009, Wisdom's root revealed: Ben Sira and election of Israel, JSJSup 139, Brill, Leiden, The Netherlands.

Horsley, R.A., 2005, 'The politics of cultural production in Second Temple Judea: Historical context and political-religious relations of the scribes who produced 1 Enoch, Sirach, and Daniel', in L.M. Wills \& B.G. Wright III (eds.), Conflicted boundaries in wisdom and apocalypticism, SBLSymS 35, pp. 123-145, Society of Biblical Literature, Atlanta, GA.

Jevrell, J., 1960, Imago Dei, Vandenhoeck und Ruprecht, Göttingen.

Kugel, J.L., 1998, Traditions of the Bible: A guide to the Bible as it was at the start of the common era, Harvard University Press, Cambridge, MA.

Leiman, S.Z., 1976, The canonization of Hebrew Scripture: The Talmudic and Midrashic evidence, Archon Books, Hamden, CT.

Levison, J.R., 1988, Portraits of Adam in early Judaism: From Sirach to 2 Baruch Journal for the Pseudepigrapha Supplement Series 1, JSOT Press, Sheffield.

Marböck, J., 1999, Weisheit im Wandel: Untersuchungen zur Weisheitstheologie bei Ben Sira, Reprint, de Gruyter, Berlin.

Mermelstein, A., 2014, Creation, covenant, and the beginnings of Judaism: Reconceiving historical time in the Second Temple Period, Brill, Leiden, The Netherlands.

Murphy, R.E., 1996, The tree of life: An exploration of Biblical wisdom literature, 2nd edn., Eerdmans, Grand Rapids, MI.

Nickelsburg, G.W.E., 1981, 'Enoch, Levi, and Peter: Recipients of revelation in upper Galilee', Journal of Biblical Literature 100, 575-600. https://doi.org/10.2307/ 3266120

Perdue, L.G., 2005, 'Ben Sira and Prophets', in J. Corley \& V.T.M. Skemp (eds.), Intertextual studies in Ben Sira and Tobit: Essays in honor of Alexander A. Di Lella, CBMQSup 38, pp. 132-154, Catholic Biblical Association of America, Washington, DC.

Schnabel, E.J., 1985, Law and wisdom from Ben to Paul: A tradition historical enquiry into the relation of law, wisdom, and ethics, J. C. B. Mohr, Tübingen.

Schniedewind, W.M., 1995, The word of God in transition: From Prophet to exegete in the Second Temple Period, JSOTSup 197, Sheffield Academic Press, Sheffield.

Schniedewind, W.M., 1999, 'The chronicler as an interpreter of Scripture', in M.P. Graham \& S.L. McKenzie (eds.), The chronicler as author: Studies in text and texture, JSOTSup 263, pp. 158-180, JSOT Press, Sheffield.

Schökel, L.A., 1978, 'The vision of man in Sirach 16:24-17:14', in J.G. Gammie et al. (eds.), Israelite wisdom: Theological and literary essays in honor of Samuel Terrien, pp. 235-260, Scholars, Missoula, MT.

Scroggs, R., 1966, The last Adam: A study in Pauline anthropology, Blackwell, Oxford.

Seeligmann, I.L., 1953, 'Voraussetzungen der Midrashexegese', Supplements to Vetus Testamentum 1, 150-181.

Sheppard, G.T., 1980, Wisdom as a hermeneutical construct, Beihefte zur Zeitschrift für die alttestamentliche Wissenschaft 151, Walter de Gruyter, Berlin.

Skehan, P.W. \& Di Lella, A.A., 1987, The wisdom of Ben Sira, Anchor Bible 39, Doubleday, New York.

Stone, M.E., 1988, 'Enoch, Aramaic Levi and Sectarian origins', Journal of the Study of Judaism 19, 159-170.

Vermes, G., 1992, 'Genesis 1-3 in post-Biblical Hebrew and Aramaic literature before the Mishnah', Journal of Jewish Studies 43, 221-225.

Wright, B.G., III, 2005, 'Putting the puzzle together: Some suggestions concerning the social location of the wisdom of Ben Sira', in L.M. Wills \& B.G. Wright III (eds.) Conflicted boundaries in wisdom and apocalypticism, SBLSymS 35, pp. 89-112, Society of Biblical Literature, Atlanta, GA. 